\title{
Affiliation of seed size with germination aspects and morphological traits in safflower (Carthamus tinctorius L.)
}

\author{
Mirshekarnezhad B. ${ }^{1 *}$, G. Abbas Akbari ${ }^{1}$, G. Ali Akbari ${ }^{1}$ and H. Sadeghi ${ }^{2}$ \\ ${ }^{1}$ Department of Agronomy and Plant Breeding, Aboureihan College, University of Tehran, Iran. \\ ${ }^{2}$ Seed and Plant Certification and Registration Institute, Karaj, Iran.
}

Accepted August 21, 2013

\begin{abstract}
Affiliation of seed size with germination rate and percentage, seedling emergence rate and percentage, $50 \%$ mean emergence time, cumulative emergence rate, through 4 Safflower cultivars (Isfahan, Goldasht, Padideh, and Sina), in three different sizes of seed, were investigated under two separate experimental conditions in the field and laboratory of Seed and Plant Certification and Registration Institute Karaj-Iran, during 2008 to 2010. Both experiments were conducted in a factorial arrangement based on randomized complete block design, with three replications. The field results showed that cultivars Goldasht and Padideh were superior compare to other cultivars and large seeds with the highest seedling emergence rate, 1000-SW, and seed yield were superior to control and small. In the laboratory, morphological traits consisted of germination percentage, fresh and dry weight of root and shoot were significantly different, so that cultivars Goldasht and padideh with large seeds displayed better reaction. Thus, due to display better performance by cultivars Goldasht and Padideh, also creating vigorous seedlings by large seeds, using cultivars with adequate food storage as well as selecting large seeds with more germination potential to obtain higher yield and good plant establishment should take into consideration.
\end{abstract}

Key words: Cultivar, Goldasht, mean germination time, morphological traits, vigorous seedling.

\section{INTRODUCTION}

Safflower is a versatile crop that can add considerable value to cropping systems by playing various strategic roles. Safflower was particularly important as an oil and pigment in southern Asia (Iran, Afghanistan, and India), As for all crops, planting seed should be genetically pure, free from seed borne diseases, have a high germination percentage $(>80 \%)$ and be free from weed and other crop seeds. Many suppliers can provide a copy of equality certificate on request, otherwise samples can be sent to an accredited laboratory for testing. The longevity of oilseeds under normal silo conditions is limited, so fresh seed should be used where possible (http://www. Australianoilseeds.com/-data/assets/pdf, 2013). In general, seed size has effects on many characters both in the field and laboratory tests. Seed size is an important seed quality characteristic affected by variety, environment and management practices. Seed may be viable and germinate but not emerge. A crust may form and inhibit 
emergence particularly on certain soils or if clear and windy days follow planting.

Crust formation may also be a problem when planting into cold soils, where seed germination and emergence are slowed by low soil temperature (Mike, 2004). Percent of seed emergence and seedling emergence rate are the characteristics that could be observed in the field and could be used as an indicator of seed vigor. These characters usually differ under field stresses such as low temperature, wet or crusted soil in which small seeds of soybean and common bean perform better than large seeds due to seedling from small seeds were less damaged than large seeds (Hoy and Gamble, 1987; Sexton et al., 1994), while the large seeds of winter wheat (Chastain et al., 1995) and mung bean (Amin, 1999) under the same conditions tended to do better in germination. Variation in seed size of chickpea is associated with geographical effects on genetic factors, irregular flowering, number of seeds per pod, and number of pods per plant (Pedersen et al., 1961; Smithson et al., 1985; Miller et al., 2002).

Also, several studies reported that, different sizes of sorghum seeds (Suh et al., 1974), and soybean seeds (Sexton et al., 1994) did not affect yield of these crops. (Singh et al., 1972) reported that, large seeds of soybean had greater supply of stored energy to support early seedling growth and subsequently affected plant growth and development. Similar result obtained by Roy et al. (2008) in rice, implied that, germination rate and seedling vigor index increased with the increase of seed size, while Kaya and Day (2008) reported that, the use of large seeds produced more vigorous seedlings under non saline conditions but the superiority was used up under saline conditions.

However, seed size has been considered to be a significant factor only during the early stage of plant growth, nevertheless, Amin (1999) reported that, $50 \%$ of large-seeded mung bean matured earlier than that of small-seeded type. Despite large seed has an advantage of having higher stored energy supply but not all reports demonstrate the effects of seed size on the yield. According to previous studies, planting seed from crops which experience an extend period of warm, wet weather prior to harvest should be avoided. These conditions favor the development of Alternaria which can infect seed and transmit the disease to the next crop. Alternaria can cause newly planted seed to rot in the soil or the damping off of seedlings. The germination percentage of seed can also be markedly reduced by rain on mature crops which causes sprouting in the head (http://www. Australianoilseeds.com/-data/assets/pdf, 2013).

Furthermore, undesirable seed and seeds with low viability which create feeble seedlings lead to minimum germination percentage while, seeds with proper size cause to stability in field emergence during next stages of plant growth. Therefore, this study was conducted to evaluate the affiliation of seed size with germination and its effect on seedling emergence rate, yield and yield components of safflower.

\section{MATERIALS AND METHODS}

This research was carried out via two separate experiments, in the laboratory and research farm of Seed and Plant Certification and Registration Institute, Karaj - Iran, during (2008 to 2010 season). The farm is located at $35^{\circ} 59^{\prime} \mathrm{N}$ latitude, $50^{\circ} 75^{\prime} \mathrm{E}$ longitude, and $1313.00 \mathrm{~m}$ of altitude. Soil texture in research farm was loamy clay (Zahedi et al., 2012).

\section{Laboratory trial}

In the laboratory, experimental treatments involved 4 safflower cultivars (Isfahan, Goldasht, Padideh and Sina), in 3 sizes of seed. The seed samples were obtained from Seed and Plant Breeding Institute Karaj-Iran. The seeds were prepared according to their diameters using proper sieves:

(1) Small: 2.0 to $3.0 \mathrm{~mm}$

(2) Large: $>3.0 \mathrm{~mm}$

(3) Control: no sorting

After treating the seeds with fungicide, 16 replicates of 25 seeds for each cultivar of 3 different sizes were prepared in 3 replicates, the samples were placed between 2 rolled filter papers (Whatman \#2) and dampened with water then the whole rolled papers were put into a sealed plastic bag and placed in growth chamber at $25^{\circ} \mathrm{C}$. A seed was considered to be germinated when the emerging radical elongated to $2.0 \mathrm{~mm}$. Germination percentage (GP) recorded every $24 \mathrm{~h}$ for 10 days and germination rate was computed by using the following formula as stated by Maguire (1962). After fixing the number of sprouts at the end of $10^{\text {th }}$ day, randomly 10 sprouts were selected, after that sprout length, root and shoot lengths were measured in centimeter, also fresh and dry weights of root and shoot were separately determined in grams.

$$
\text { Germination rate }=\frac{\text { No. of normal seedlings }}{\text { Days to first count }}+\ldots+\frac{\text { No. of normal seedlings }}{\text { Days to final count }}
$$

\section{Field trial}

By using a randomized complete block design in factorial arrangement with 3 replications, randomly the treatments were distributed to experimental plots formed by $3.00 \mathrm{~m}$ long with rows at $5.0 \mathrm{~m}$ spacing. Then in each plot the second row was separated into two distances ( 0.5 and $2.5 \mathrm{~m}$ lengths) so that per $2.5 \mathrm{~m}$ length involved 40 seeds at a space of $5.0 \mathrm{~cm}$ between them. The sprouts in this line were counted daily to determine seedling emergence rate and percentage (SER), (SEP), 50\% mean emergence time (MET), and cumulative emergence rate (CER). Moreover to determine yield and yield components, after discarding border rows about 16 plants from each plot were harvested $\left(1.0 \mathrm{~m}^{2}\right)$. Three plants of each plot were selected randomly, then the characters comprised of plant number per plot, head number per plant, seed number per head, seed number per plant, 1000-seeds mass (in grams), head diameter (in millimeter) and plant height (in centimeter) were evaluated.

\section{Statistical analysis}

Analysis of variance (ANOVA) for all investigated parameters and correlation analysis were performed by using MSTAT-C computer software, version 2.10 (Michigan State University), and SAS 
Table 1. Analysis of variance for measured characters in the laboratory.

\begin{tabular}{|c|c|c|c|c|c|c|c|c|c|c|c|}
\hline \multicolumn{12}{|c|}{ Mean squares (ms) } \\
\hline S.O.V & & df & $\begin{array}{c}\text { Germination } \\
\text { percentage (\%) }\end{array}$ & $\begin{array}{l}\text { Germination } \\
\text { rate }(\mathrm{ng} / \mathrm{d})^{\star}\end{array}$ & $\begin{array}{c}\text { Fresh weight } \\
\text { of shoot }\end{array}$ & $\begin{array}{c}\text { Dry weight } \\
\text { of Shoot }\end{array}$ & $\begin{array}{l}\text { Fresh weight } \\
\text { of root }\end{array}$ & $\begin{array}{l}\text { Dry weight } \\
\text { of root }\end{array}$ & $\begin{array}{l}\text { Sprout } \\
\text { length }\end{array}$ & $\begin{array}{l}\text { Shoot } \\
\text { length }\end{array}$ & $\begin{array}{c}\text { Root } \\
\text { length }\end{array}$ \\
\hline $\mathrm{R}(\operatorname{Rep})$ & & 2 & 25.86 & $7.244^{\mathrm{ns}}$ & $0.5045^{\text {ns }}$ & 0.000004 & $0.000784^{\mathrm{ns}}$ & $0.0000485 \mathrm{~ns}$ & $4.4955^{\star *}$ & $5.5151^{* *}$ & $0.2773^{\text {ns }}$ \\
\hline Cultivar (C) & & 3 & $896.07^{\star *}$ & $53.317^{* *}$ & $2.2588^{\star *}$ & $0.003155^{\star *}$ & $0.050143^{\star *}$ & $0.0000419 \mathrm{~ns}$ & $1.8474^{*}$ & $2.7507^{\star *}$ & $3.2101^{* *}$ \\
\hline Seed size (S) & & 2 & $146.19^{\star *}$ & $17.780^{* *}$ & $0.812^{\star *}$ & $0.009691^{* *}$ & $0.037417^{*}$ & $0.0013908^{\star *}$ & $0.5139^{\mathrm{ns}}$ & $0.0043^{\mathrm{ns}}$ & $0.2338^{\text {ns }}$ \\
\hline $\mathrm{C} \times \mathrm{S}$ & & 6 & $16.27^{\mathrm{ns}}$ & $0.810^{\mathrm{ns}}$ & $0.0347^{\text {ns }}$ & $0.000221^{\mathrm{ns}}$ & $0.00071^{\text {ns }}$ & $0.0000017^{\mathrm{ns}}$ & $0.1869^{\text {ns }}$ & $0.2574^{\mathrm{ns}}$ & $0.2539^{\text {ns }}$ \\
\hline \multirow[t]{2}{*}{ Error } & & 22 & 12.53 & 2.843 & 0.09165 & 0.0001458 & 0.006765 & 0.0000303 & 0.5437 & 0.3966 & 0.4959 \\
\hline & C.V.(\%) & & 4.66 & 9.29 & 11.59 & 9.14 & 22.92 & 18.91 & 4.32 & 11.61 & 6.13 \\
\hline
\end{tabular}

${ }^{* *}=$ Significant at $1 \%$ level, ${ }^{*}=$ significant at $5 \%$ level, $\mathrm{ns}=$ non-significant, ${ }^{*}=$ number of germination per day.

Table 2. Means comparison of laboratory characters using Duncan multiple range test (DMRT).

\begin{tabular}{|c|c|c|c|c|c|c|c|c|c|c|}
\hline Variable & S.O.V & $\begin{array}{c}\text { Germination } \\
\text { percentage (\%) }\end{array}$ & $\begin{array}{l}\text { Germination } \\
\text { rate }(\mathrm{ng} / \text { day })^{*}\end{array}$ & $\begin{array}{c}\text { Fresh weight } \\
\text { of shoot }(\mathrm{g})\end{array}$ & $\begin{array}{l}\text { Dry weight } \\
\text { of shoot }(\mathrm{g})\end{array}$ & $\begin{array}{c}\text { Fresh weight } \\
\text { of root }(\mathrm{g})\end{array}$ & $\begin{array}{l}\text { Dry weight } \\
\text { of root }(\mathrm{g})\end{array}$ & $\begin{array}{c}\text { Sprout } \\
\text { length }(\mathrm{cm})\end{array}$ & $\begin{array}{c}\text { Shoot } \\
\text { length }(\mathrm{cm})\end{array}$ & $\begin{array}{c}\text { Root } \\
\text { length }(\mathrm{cm})\end{array}$ \\
\hline \multirow{4}{*}{ Cultivar } & (Esfahan) & $80.56^{b}$ & $20.41^{\mathrm{a}}$ & $2.16^{\mathrm{c}}$ & $0.114^{\mathrm{C}}$ & $0.31^{b}$ & $0.02944^{\mathrm{a}}$ & $16.57^{b}$ & $5.59^{\mathrm{a}}$ & $10.79^{c}$ \\
\hline & (Goldasht) & $74.22^{c}$ & $17.95^{b}$ & $2.88^{b}$ & $0.157^{\mathrm{a}}$ & $0.28^{b}$ & $0.04933^{a}$ & $17.52^{\mathrm{a}}$ & $5.88^{\mathrm{a}}$ & $11.26^{b c}$ \\
\hline & (Padideh) & $86.00^{\mathrm{a}}$ & $19.42^{\mathrm{ab}}$ & $3.18^{a}$ & $0.135^{\mathrm{b}}$ & $0.44^{\mathrm{a}}$ & $0.04433^{a}$ & $17.36^{\mathrm{a}}$ & $5.60^{\mathrm{a}}$ & $11.77^{\mathrm{ab}}$ \\
\hline & (Sina) & $62.78^{d}$ & $14.83^{\mathrm{C}}$ & $2.23^{c}$ & $0.122 b^{c}$ & $0.40^{\mathrm{a}}$ & $0.03089^{a}$ & $16.79^{\mathrm{ab}}$ & $4.62^{b}$ & $12.16^{\mathrm{a}}$ \\
\hline \multirow{3}{*}{$\begin{array}{l}\text { Seed } \\
\text { size }\end{array}$} & (Control) & $73.75^{b}$ & $19.54^{\mathrm{a}}$ & $2.34^{b}$ & $0.105^{c}$ & $0.304^{b}$ & $0.0197^{c}$ & $16.07^{\mathrm{a}}$ & $5.43^{\mathrm{a}}$ & $11.4^{\mathrm{a}}$ \\
\hline & (Large) & $79.92^{\mathrm{a}}$ & $17.24^{\mathrm{b}}$ & $2.86^{\mathrm{a}}$ & $0.162^{\mathrm{a}}$ & $0.415^{\mathrm{a}}$ & $0.0408^{\mathrm{a}}$ & $16.22^{\mathrm{a}}$ & $5.12^{a}$ & $11.13^{\mathrm{a}}$ \\
\hline & (Small) & $74.00^{b}$ & $17.68^{b}$ & $2.64^{\mathrm{a}}$ & $0.129^{b}$ & $0.358^{\mathrm{ab}}$ & $0.0268^{b}$ & $17.07^{\mathrm{a}}$ & $5.4^{\mathrm{a}}$ & $11.55^{\mathrm{a}}$ \\
\hline
\end{tabular}

Means within the same column, followed by the same letters are not significantly different at 0.05 level by DMRT. * $=$ Number of germination per day.

procedures (SAS Institute., 1988). Significant differences among means were compared by Duncan's multiple range test $(P<0.05)$.

\section{RESULTS AND DISCUSSION}

\section{Laboratory}

The analysis of resulting data for germination of safflower cultivars in 3 sizes indicated that, there were significant differences among cultivars for all measured traits except dry weight of root (Table 1). According to means comparison, the cultivar Padideh showed the highest amount of GP (86\%), and greater fresh weight of shoot $(3.18 \mathrm{~g})$, and the cultivar Goldasht stood out with greatest dry weight of shoot (0.157) (Table 2). Also among seed sizes the large seeds showed the highest amount of GP (79.92\%), fresh and dry weight of root presented better development compare to control and small. The results are in agreement with the observations of Kaya and Day (2008),
Saranga et al. (1998) on sunflower, Roy et al. (2008) on rice and Chiangmai et al. (2006) on mung bean, they found better behavior of large seeds for most of the investigated parameters.

\section{Field}

The results of investigated parameters showed significant differences $(P<0.01)$ among cultivars for all traits except number of plant per plot (Table 
Table 3. Analysis of variance for measured characters in the field.

\begin{tabular}{|c|c|c|c|c|c|c|c|c|c|c|c|c|c|}
\hline \multicolumn{14}{|c|}{ Mean squares (MS) } \\
\hline S.O.V & & df & $\begin{array}{c}\text { Seedling } \\
\text { emergence } \\
\text { percentage (\%) }\end{array}$ & $\begin{array}{l}50 \% \text { Mean } \\
\text { germination } \\
\text { time }\end{array}$ & $\begin{array}{l}\text { Seedling } \\
\text { emergence } \\
\text { rate }(n s e / d)^{*}\end{array}$ & $\begin{array}{c}\text { Cumulative } \\
\text { emergence rate } \\
\text { (nse/d) })^{*}\end{array}$ & $\begin{array}{l}\text { Plant } \\
\text { height } \\
(\mathrm{cm})\end{array}$ & $\begin{array}{l}1000 \text {-seed } \\
\text { weight } \\
\text { (g) }\end{array}$ & $\begin{array}{l}\text { Plant } \\
\text { number } \\
\text { (n) }\end{array}$ & $\begin{array}{l}\text { Head per } \\
\text { plant (n) }\end{array}$ & $\begin{array}{c}\text { Seed } \\
\text { per head } \\
\text { (n) }\end{array}$ & $\begin{array}{c}\text { Head } \\
\text { diameter } \\
(\mathrm{mm})\end{array}$ & $\begin{array}{l}\text { Seed } \\
\text { yield } \\
\left(\mathrm{g} / \mathrm{m}^{2}\right)\end{array}$ \\
\hline $\mathrm{R}(\operatorname{Rep})$ & & 2 & $261.78^{* *}$ & $0.043^{* *}$ & $0.72^{* *}$ & $72.181^{\star *}$ & $5.58^{\mathrm{ns}}$ & $4.565^{\mathrm{ns}}$ & $91.194^{*}$ & $37.75^{\text {ns }}$ & $24.78^{\text {ns }}$ & $1.08^{\mathrm{ns}}$ & $1406.86^{* *}$ \\
\hline Cultivar(C) & & 3 & $1100.8^{* *}$ & $0.071^{* *}$ & $2.31^{\star *}$ & $209.465^{\star *}$ & $814.92^{* *}$ & $1132.9^{* *}$ & $42.59^{\text {ns }}$ & $1681.0^{* *}$ & $1306.296^{* *}$ & $57.124^{* *}$ & $14285.36^{* *}$ \\
\hline Seed size (S) & & 2 & $435.53^{* *}$ & $0.085^{\star *}$ & $2.48^{* *}$ & $84.866^{* *}$ & $64.33^{\text {ns }}$ & $340.57^{* *}$ & $17.528^{\text {ns }}$ & $112.58^{\mathrm{ns}}$ & $36.11^{\mathrm{ns}}$ & $3.961^{\mathrm{ns}}$ & $6161.86^{* *}$ \\
\hline $\mathrm{C} \times \mathrm{S}$ & & 6 & $27.194^{\mathrm{ns}}$ & $0.005^{\text {ns }}$ & $0.048^{\text {ns }}$ & $2.040^{\text {ns }}$ & $20.22^{\text {ns }}$ & $17.43^{\text {ns }}$ & 20.23 ns & $449.81^{*}$ & $42.520^{\mathrm{ns}}$ & $1.148^{\mathrm{ns}}$ & $224.08^{\text {ns }}$ \\
\hline \multirow[t]{2}{*}{ Error } & & 22 & 33.051 & 0.004 & 0.108 & 3.964 & 62.49 & 13.84 & 20.982 & 124.93 & 68.475 & 4.164 & 196.89 \\
\hline & C.V.(\%) & & 7.74 & 8.20 & 8.87 & 9.39 & 7.01 & 8.03 & 24.39 & 29.54 & 18.08 & 7.11 & 6.80 \\
\hline
\end{tabular}

${ }^{* *}=$ Significant at $1 \%$ level; ${ }^{*}=$ significant at $5 \%$ level, ns $=$ non-significant, ${ }^{*}=$ number of seedling per day.

Table 4. Means comparison of field characters using Duncan multiple range test (DMRT).

\begin{tabular}{|c|c|c|c|c|c|c|c|c|c|c|c|}
\hline Variable & S.O.V & $\begin{array}{c}\text { Seedling } \\
\text { emergence } \\
\text { percentage (\%) }\end{array}$ & $\begin{array}{c}\text { Mean } \\
\text { germination } \\
\text { time } n g / d)^{*}\end{array}$ & $\begin{array}{l}\text { Seedling } \\
\text { emergence } \\
\text { rate }(\mathbf{g})\end{array}$ & $\begin{array}{l}\text { Cumulative } \\
\text { emergence } \\
\text { rate }(\mathbf{g})\end{array}$ & $\begin{array}{l}\text { Plant } \\
\text { height }\end{array}$ & $\begin{array}{l}1000- \\
\text { SW }\end{array}$ & $\begin{array}{l}\text { Head per } \\
\text { plant }\end{array}$ & $\begin{array}{l}\text { Seed } \\
\text { per } \\
\text { head }\end{array}$ & $\begin{array}{l}\text { Head } \\
\text { diameter } \\
(\mathrm{cm})\end{array}$ & $\begin{array}{l}\text { Seed yield } \\
\qquad\left(g / \mathrm{m}^{2}\right)\end{array}$ \\
\hline \multirow{4}{*}{ Cultivar } & (Esfahan) & $75.889^{b}$ & $0.802^{\mathrm{b}}$ & $22.189^{b}$ & $22.189^{b}$ & $125.333^{\mathrm{a}}$ & $37.463^{c}$ & $38.000^{b}$ & $53.222^{a}$ & $28.200^{\mathrm{b}}$ & $204.778^{b}$ \\
\hline & (Goldasht) & $75.556^{b}$ & $0.803^{b}$ & $22.167^{\mathrm{b}}$ & $22.167^{\mathrm{b}}$ & $114.111^{b}$ & $62.771^{a}$ & $23.556^{\mathrm{C}}$ & $43.444^{b}$ & $30.956^{a}$ & $255.444^{a}$ \\
\hline & (Padideh) & $86.222^{a}$ & $0.902^{a}$ & $25.967^{\mathrm{a}}$ & $25.967^{\mathrm{a}}$ & $103.111^{\mathrm{c}}$ & $42.358^{b}$ & $33.556^{\mathrm{bc}}$ & $56.667^{\mathrm{a}}$ & $30.333^{a}$ & $207.111^{b}$ \\
\hline & (Sina) & $59.444^{c}$ & $0.684^{\mathrm{C}}$ & $14.478^{c}$ & $14.478^{c}$ & $108.444^{\mathrm{bc}}$ & $42.730^{b}$ & $56.222^{\mathrm{a}}$ & $29.778^{c}$ & $25.378^{c}$ & 157.889 \\
\hline \multirow{3}{*}{ Seed size } & (Control) & $68.833^{b}$ & $0.879^{a}$ & $4.125^{a}$ & $23.950^{\mathrm{a}}$ & $110.08^{a}$ & $41.379^{c}$ & $35.0^{\mathrm{a}}$ & $47.17^{\mathrm{a}}$ & $29.38^{a}$ & $186.0^{\mathrm{C}}$ \\
\hline & (Large) & $80.750^{\mathrm{a}}$ & $0.711^{\mathrm{C}}$ & $3.225^{\mathrm{c}}$ & $18.642^{\mathrm{c}}$ & $114.25^{\mathrm{a}}$ & $51.967^{a}$ & $37.42^{\mathrm{a}}$ & $43.83^{\mathrm{a}}$ & $28.46^{\mathrm{a}}$ & $230.750^{\mathrm{a}}$ \\
\hline & (Small) & $73.250^{\mathrm{b}}$ & $0.804^{b}$ & $3.783^{\mathrm{b}}$ & $21.008^{b}$ & $113.92^{\mathrm{a}}$ & $45.645^{b}$ & $41.08^{\mathrm{a}}$ & $46.33^{a}$ & $28.32^{\mathrm{a}}$ & $202.167^{b}$ \\
\hline
\end{tabular}

Means within the same column, followed by the same letters are not significantly different at 0.05 level by DMRT. * Number of germination per day.

3. Also significant differences observed among different sizes of seed for characters SER, SEP, MET, CER, 1000-SW and seed yield, for which cultivar Padideh with higher amount of SEP $(80.75 \%)$, MET $(0.902 \%)$, SER (25.96), CER (25.96), then cultivar Goldasht with greater 1000SW $(62.77 \mathrm{~g})$ and seed yield $\left(255.4 \mathrm{~g} / \mathrm{m}^{2}\right)$ were superior to other cultivars. Among seed sizes large seeds with the highest amount of SEP $(80.7 \%)$ $1000-S W(51.96 \mathrm{~g})$, seed yield $\left(230.7 \mathrm{~g} / \mathrm{m}^{2}\right)$, plant height $(114.25 \mathrm{~cm})$ were superior, after that control seeds performed better reaction compare to small in each cultivar as shown in Table 4. Similar results obtained by Elliott and Rakow (1999) on oilseed rape and Matrinelli- Seneme et al. (2000) on corn seed. Apart from seed size variation among varieties, each variety may have unique features in which it can adapt to a specific condition (Amin, 1999). Large seeds could produce larger bean sprouts including sprout weight, head diameter, and stem diameter as well. This can be explained that, larger cotyledons had produced larger hypocotyls Black (1956), and Burris et al. (1971). Seed size $\times$ cultivar interaction 


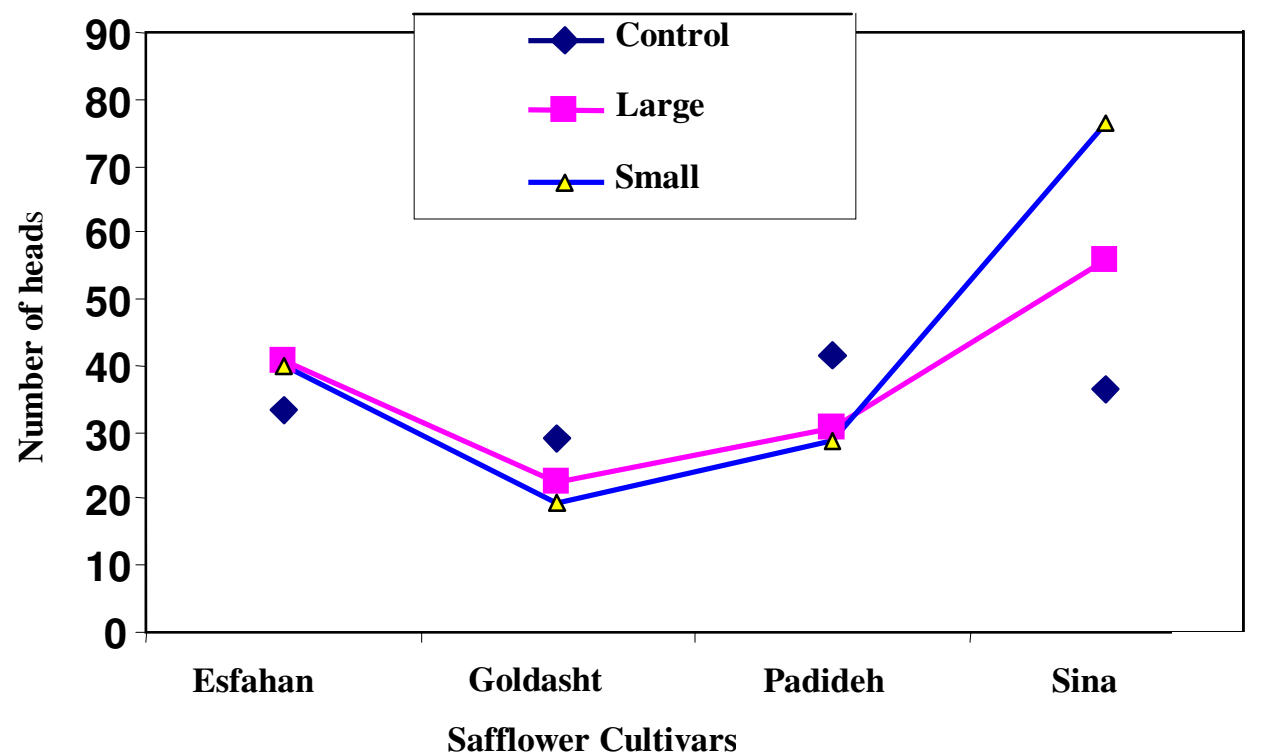

Figure 1. Cultivar $\times$ Seed size interaction on number of head per plant.

only for the number of heads per plant was significant $(P$ $<0.05$ ), and its performance is shown on Figure 1 . The coefficient of variation were from $6.8 \%$ (seed yield) to $29.5 \%$ (head per plant) which is an indicator of accurate performance of experiments and records of agronomic characters.

\section{Correlation coefficient between laboratory and field traits}

The evaluation of correlation coefficients between investigated parameters in the field and laboratory disclosed that, SEP in the field was positively correlated with GP and fresh weight of shoot in the laboratory as shown in Table 5. Positive correlation observed between SEP in the field with shoot length in the laboratory, on the other hand MET had positive correlation with GR but revealed negative correlation with dry weight of root. SER in the field with GR and shoot length had positive correlation, but indicated negative correlation with dry weight of root in the laboratory. There was positive correlation between CER in the field with GR, GP and shoot length under laboratory condition. Number of seeds per head was positively correlated with GR and GP. In addition positive correlation was found between head diameter with the characters including GR and GP, sprout length and shoot length. It figured out that, large seed with more germination vigor was the character which could be able to produce sprouts with better germination behavior and had compensated seed yield and other yield components. Seed yield disclosed positive correlation with fresh and dry weight of root and shoot length in the laboratory that originated from producing sprouts with higher weight by large seeds due to their ability for having more efficient photosynthesis under non-stress condition in the laboratory.

One observation on the effect of seed size and seed number was that, both characteristics affected yield. However, the characters such as number and seed size may both affect and compensate each other in determining yield (Spaeth and Sinclair, 1984; Board et al., 1999) and the main factor which directly contributed to yield was dependent upon plant species and varieties. The correlation between yield and yield components with seed size has been estimated in different varieties and crop plants but not all reports presented the same conclusions. Length and width of soybean seeds were positively correlated with final seed size (Fraser et al., 1982) but 1000-kernel weight of seeds harvested and the seeds per head of spring wheat were not significantly correlated with initial seed size Austenson and Walton (1970).

\section{Conclusion}

In conclusion, regarding background of each cultivar that influences seed vigor and plant establishment in the field, cultivars Goldasht and Padideh were superior to other cultivars for most of the investigated characters associated with viability. Subsequently, germination characteristics were significantly affected with seed size and among 3 sizes of seed, large seeds displayed better performance than other sizes of seed. Considering grain as the final sink during loading process with assimilate at the final step of ripening; imply that larger seeds with bigger area of cotyledon could be able to store much sufficient food in this period rather than small.Due to use of excessive seed at planting time by farmers that arisen 
Table 5. Correlation coefficients among measured characters in the field and laboratory.

\begin{tabular}{|c|c|c|c|c|c|c|c|c|c|}
\hline Field & $\begin{array}{c}\text { Germination } \\
\text { percentage (\%) }\end{array}$ & $\begin{array}{l}\text { Germination } \\
\text { rate }(\mathrm{ng} / \mathrm{d})^{\star}\end{array}$ & $\begin{array}{c}\text { Fresh } \\
\text { weight } \\
\text { of shoot }(\mathrm{g})\end{array}$ & $\begin{array}{c}\text { Dry weight } \\
\text { of shoot } \\
\text { (g) }\end{array}$ & $\begin{array}{c}\text { Fresh } \\
\text { weight } \\
\text { of root }(\mathrm{g}) \\
\end{array}$ & $\begin{array}{l}\text { Dry weight } \\
\text { of root }(g)\end{array}$ & $\begin{array}{c}\text { Sprout } \\
\text { length } \\
(\mathrm{cm})\end{array}$ & $\begin{array}{c}\text { Shoot } \\
\text { length } \\
(\mathrm{cm})\end{array}$ & $\begin{array}{c}\text { Root } \\
\text { length } \\
\text { (cm) }\end{array}$ \\
\hline Seedling emergence percentage (\%) & $0.936^{\star *}$ & 0.477 & $0.762^{* *}$ & 0.501 & 0.260 & 0.377 & 0.166 & $0.658^{*}$ & -0.462 \\
\hline Mean germination time (\%) & 0.454 & $0.777^{\star *}$ & 0.209 & -0.360 & -0.297 & $-0.672^{*}$ & 0.526 & 0.489 & -0.093 \\
\hline Seedling emergence rate (nse/day) ${ }^{*}$ & 0.491 & $0.836^{\star *}$ & 0.163 & -0.401 & -0.453 & $-0.696^{*}$ & 0.533 & $0.622^{*}$ & -0.263 \\
\hline Cumulative emergence rate (nse/day) & $0.675^{\star}$ & $0.856^{* *}$ & 0.365 & -0.203 & -0.300 & -0.503 & 0.498 & $0.685^{\star}$ & -0.317 \\
\hline Plant height $(\mathrm{cm})$ & 0.108 & 0.275 & -0.473 & -0.007 & -0.498 & 0.016 & -0.503 & 0.327 & $-0.788^{* *}$ \\
\hline 1000-Seed weight (g) & -0.015 & -0.303 & 0.508 & $0.811^{* *}$ & -0.163 & 0.485 & 0.471 & 0.401 & -0.130 \\
\hline Plant number & 0.376 & 0.373 & 0.021 & 0.355 & -0.358 & 0.151 & 0.028 & $0.662^{*}$ & -0.575 \\
\hline Head per plant (n) & -0.442 & -0.499 & -0.465 & -0.342 & 0.346 & 0.062 & -0.443 & $-0.665^{*}$ & 0.358 \\
\hline Seed per head (n) & $0.836^{\star *}$ & $0.866^{\star *}$ & 0.359 & -0.127 & -0.090 & -0.259 & 0.135 & 0.574 & -0.499 \\
\hline Head diameter (mm) & $0.617^{\star}$ & $0.631^{*}$ & $0.616^{*}$ & 0.261 & -0.323 & -0.149 & $0.730^{\star *}$ & $0.804^{\star *}$ & -0.322 \\
\hline Seed yield $\left(\mathrm{g} / \mathrm{m}^{2}\right)$ & 0.527 & 0.226 & $0.616^{*}$ & $0.778^{* *}$ & -0.205 & 0.437 & 0.348 & $0.793^{\star *}$ & -0.563 \\
\hline
\end{tabular}

${ }^{* *}=$ Significant at $1 \%$ level, ${ }^{*}=$ Significant at $5 \%$ level, ${ }^{*}=$ Number of germination per day, ${ }^{*}=$ Number of seedling per day.

from uncertainty of field emergence and undesirable density, the selection of seeds based on proper size with more germination potential that would decrease the utilization of seed per hectare is recommended.

\section{ACKNOWLEDGEMENTS}

The author appreciates the faculty of Abourihan College, University of Tehran for practical guidance and the staff of Seed and Plant Certification and Registration Institute of KarajIran, for providing accommodations.

\section{REFERENCES}

Amin AD (1999). Influence of seed size on the performance of mung bean varieties under postrice and upland cropping systems. Asia regional center-AVRDC [online URL:www.arc.avrdc-org/pdf-files/Amin (17-N).

pdf] accessed on July 13, 2006.
Austenson HM, Walton PD (1970). Relationships between initial seed weight and mature plant characters in spring wheat. Can. J. Plant Sci. 50:53-58.

Black JN (1956). The influence of seed size and depth of sowing on pre-emergence and early vegetative growth in subterranean clover (Trifolium subterraneum L.). Aust. J. Agric. Res. 7:93-109.

Board JE, Kang MS, Harville BG (1999). Path analyses of the yield formation process for late-planted soybean. Agron. J. 91:128-135.

Burris JS, Edje OT, Wahab AH (1971). Effects of seed size on seedling performance in soybeans. II seedling growth and photosynthesis and field performance. Crop sci. 13:207-210. photosynthesis and field performance. Crop sci. 13:207-210.
Chastain T, Ward GKJ, Wysocki DJ (1995). Stand establishment responses of soft white wheat to seedbed residue and seed size. Crop sci. 35:213-218.

Chiangmai PN, Laosuwan P, Anyuwat AW (2006). The effect of mung bean seed size on germination ability, bean sprout production and agronomic characters. Silpakorn Univer. Int. J..6:1-2.

Elliott RH, Rakow GFW (1999). Influence of seed size on the agronomic performance of oilseed rape. AAFC Research center, 107 science place, Saskatoon, saskach ewan, Canada S7N. X2.

Fraser J, Egli DB, Leggett JE (1982). Pod and seed development in soybean cultivars with differences in seed size. Agron. J. 74:81-85.
Hoy DJ, Gamble EE (1987). Field performance in soybean with seeds of different size and density. Crop sci. 27:121126.

http://www.

Australianoilseeds.com/-data/assets/pdf-file; visited on June 26, 2013

Kaya MD, Day S (2008). Relationship between seed size and $\mathrm{Nacl}$ on germination, seed vigor and early seeding growth of sunflower. Afr. J. Agric. Res. 3(11):787-791.

Maguire JD (1962). Seed of germination-aid in selection and evaluation for seedling emergence and vigor. Crop Sci. 2:176-177.

Matrinelli-Seneme A, Zenotto MD, Nakagawa J (2000). Seed size and shap effect on corn seed quality, cultivar AL-34. Revista Brasilevia de Sementes 22(1):232-238.

Mike O (2004). Seeding Rates for Small Grains in Arizona,Cooperative Extension, College of Agriculture and Life Sciences. The University of Arizona.

Miller P, McKay K, Jenks B (2002). Montguide: Montan State University, Extension Service; 2002. Growing Chickpea in the Northern Great Plains. MT200204 AG 3/2002, (Available from: http://www.montana.edu/wwwpb/pubs/mt200204.pdf)

Pedersen MW, Jones LG, Rogers TH (1961). Producing Seeds of the Legumes. In: Stefferud A, editor. Seeds. US Department of Agriculture. pp. 171-181. Yearbook.

Roy SKS, Hamid A, Miah MG, Hashem A (2008). Seed size variation and its effects on germination and seedling vigour in Rice. J. Agron. Crop Sci. 176(2):79-82. 
Saranga Y, Levi A, Horcicka P, Wolf S (1998). Large sunflower seeds are characterized by low embryo vigor. J. Am. Soc. Hort. Sci. 123(3):470-474.

Sexton PJ, White JW, Boote KJ (1994). Yield-determining processes in relation to cultivar seed size of common bean. Crop Sci. 34:84-91.

Singh JN, Tripathi SK, Negi PS (1972). Note on the effect of seed size on germination, growth and yield of soybean (Glycine max L.). Indian J. Agric. Sci. 42(1):83-86.

Smithson JB, Thompson JA, Summerfield RJ (1985). Chickpea (Cicer arietinum L.) In: Summerfield RJ, Roberts EH, editors. Grain Legume. Crops.London: Collins Publications, pp. 312-390.
Spaeth SC, Sinclair TR (1984). Soybean seed growth. II. Individual seed mass and component compensation. Agron. J. 76:128-133.

Suh H, Casady AJ, Vanderlip RL (1974). Influence of sorghum seed weight on the performance of the resulting crop. Crop Sci. 14:835836.

Zahedi H, Shirani AH, Tohidi Moghadam HR (2012). Effect of zeolite and selenium foliar application on growth, production and some physiological attributes of three canola (Brassica Napus L.) cultivars subjected to drought stress. Revista Cientifica UDO Agricola 12(1):135-142. 